\title{
Large-scale Landscape Mapping for Environmental Risk Assessment in the Arctic of Western Siberia (Russia)
}

GI_Forum 2017, Issue 1

Page: 3 - 14

Full Paper

Corresponding Author:

d.m.marinskikh@utmn.ru

DOI: 10.1553/giscience2017_01_s3

Dmitry Marinskikh, Aleksandr Marshinin and Ildar Idrisov

Tyumen State University

\begin{abstract}
Landscape mapping is widely used for the implementation of oil and gas development projects in the Russian Arctic, in particular for environmental impact and risk assessment. Large-scale landscape maps $(1: 25,000-1: 100,000)$ have already been developed within these types of studies for the Yamal project and Tambey group of fields, and for fields in the southern Gydan Peninsula and Nadym-Pur-Taz interfluve. In this study, methods of large-scale inventory landscape mapping were developed and evaluation and advisory maps were generated. Modern research and mapping methods were applied in the preparation of a landscape map of Bely Island (in the Kara Sea). The final data processing included the correction of the planimetric part of the landscape map, and adding information about terrain types and types of landscape units to the database. The configuration of the map was complemented by images and data about areas of the main map units. The morphometric analysis of the research areas was carried out using ALOS World 3D and AsterDEM in the program SAGA.
\end{abstract}

\section{Keywords:}

landscape research, mapping, terrain, Arctic

\section{Introduction}

In this study, Arctic landscapes were considered as natural complexes of the northern part of Western Siberia within the Arctic zone of the Russian Federation of the Yamalo-Nenets Autonomous Okrug, where the authors have conducted several studies of large-scale mapping over the last twenty years (Kozin et al., 1996, 2009; Idrisov et al. 2006, 2015). Landscape mapping was carried out mainly due to oil and gas development in the territory, in particular, for environmental impact assessment of oil and gas fields, environmental baseline assessment, and environmental engineering surveys, for which large-scale landscape maps are necessary.

The authors prepared large-scale landscape maps $(1: 25,000$ to 1:100,000) within the YamaloNenets Autonomous Okrug for the territory covered by the Yamal project and Tambey group of fields (Yamal Peninsula), for various oil and gas fields in the southern part of the 
Gydan Peninsula and the Nadym-Pur-Taz interfluve (Marinskikh, 2003; Idrisov et al., 2006, 2015) (see Figure 1). These studies are based on a Kozin's (2007) methodology for landscape and ecological analysis of oil and gas areas. The article summarizes several instances of largescale landscape mapping in the Arctic using contemporary methods for landscape mapping, and the outcomes.

\section{Research methods and landscape mapping}

Landscape structure analysis for mapping purposes was conducted through a combination of fieldwork and remote research methods. Landscape fieldwork was guided by general complex physical-geographic research methods (Beruchashvili \& Zhuchkova, 1997). Relief forms, soil and vegetation cover, and the depth of seasonal thawing of the permafrost were analysed in the field; landscape position and lithogenetic surface were identified (e.g. a floodplain, a terrace, a divide, etc.). Mesorelief forms as important factors of landscape differentiation were taken into account especially. The basic morphometric parameters of relief forms were considered within the classification of landscapes, at the level of the types of landscape units (e.g. urochishches or microgeochores) (Kotlyakov \& Komarova, 2007).

A number of scientific and methodical approaches (Milkov, 1970; Kozin, 2007) were assumed for classification purposes when landscape map legends were being prepared. Table 1 illustrates the classification (taxonomic) levels, leading signs and factors of landscape classification. The typological range of taxonomic units is used for performing large-scale landscape mapping. Types of terrain and types of landscape units are the main classification units for landscape mapping. The type of terrain is a fairly uniform territory from the point of view of an environment, e.g. floodplain, hilly forest-tundra (Milkov, 1966). Every type of terrain in the research area consists of a significant number of landscape units. Common landscape features are caused by the location and nature of the landscape-forming processes. Genetic and morphological similarities of dominant and characteristic landscape units, the combination of lithologic-facial complexes, and the degree of territory drainage form the basis for the differentiation between types of terrain. The essential value of terrain differentiation types is provided by flooding duration (on floodplains), type and depth of peat (within swamp landscapes), drainage conditions, and features of the permafrost. 


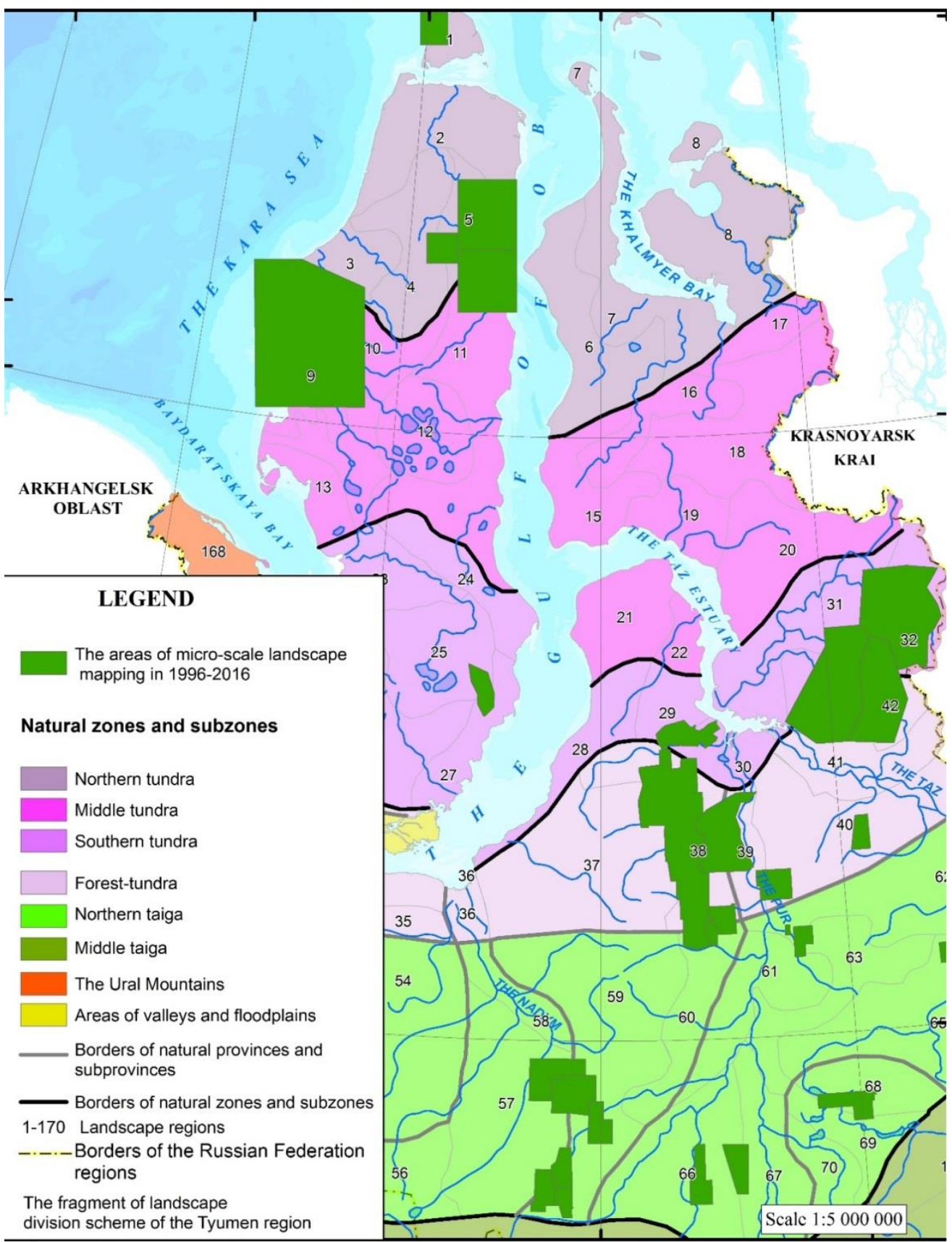

Figure 1: Part of the authors' large-scale Western Siberia Arctic landscape map, showing the landscape divisions for the Tyumen region 
Figure 1 illustrates a scheme of landscape organization in the northern part of Western Siberia. Natural zones and subzones include natural sectors and subsectors ('provinces' and 'sub-provinces' in Russian terminology) and landscape regions.

The second important taxonomic unit of large-scale mapping is the type of landscape unit. A landscape unit is a particular complex of facies which is well isolated in nature by relief and the non-uniform structure of its soils (Milkov, 1966). The main features for differentiating types of landscape unit are the vegetation and microrelief seen in a relatively uniform lithologic-facial complex. The main identifying characteristic is the structural and dynamic unity of a facies.

Table 1: Landscape classification factors

\begin{tabular}{|c|c|c|}
\hline Classification level & Leading signs & Classification factors \\
\hline $\begin{array}{l}\text { 1. Variant of } \\
\text { landscape sphere }\end{array}$ & $\begin{array}{l}\text { Dominance of substances } \\
\text { phase and contact type of } \\
\text { geosphere interactions }\end{array}$ & $\begin{array}{l}\text { Interaction of hydrosphere and lithosphere. } \\
\text { Presence or absence of water area and land. } \\
\text { Distribution of depths on shelf and in bays. } \\
\text { Homogeneous texture of satellite imagery } \\
\text { (planetary generalization level) }\end{array}$ \\
\hline $\begin{array}{l}\text { 2. Group of } \\
\text { landscape types }\end{array}$ & $\begin{array}{l}\text { Energy supply sources of } \\
\text { landscapes }\end{array}$ & $\begin{array}{l}\text { Radiative balance. Photostructural unity seen in } \\
\text { space images (continental generalization level) }\end{array}$ \\
\hline $\begin{array}{l}\text { 3. Landscape type } \\
\text { and subtype }\end{array}$ & $\begin{array}{l}\text { Zonal type of climate and } \\
\text { leading physical- } \\
\text { geographic processes }\end{array}$ & $\begin{array}{l}\text { Zonal climate type and subtypes. Homogeneous } \\
\text { texture seen in space images (continental } \\
\text { generalization level) }\end{array}$ \\
\hline 4. Landscape class & $\begin{array}{l}\text { Orographical } \\
\text { differentiation within plain } \\
\text { landscape class }\end{array}$ & $\begin{array}{l}\text { Absolute and comparative altitudes. } \\
\text { Morphostructure types of regional dimensions. } \\
\text { Interconnection of orographical elements with } \\
\text { moistening types and vegetation formations. } \\
\text { Homogeneous texture in space images (regional } \\
\text { generalization level) }\end{array}$ \\
\hline 5. Landscape kind & $\begin{array}{l}\text { Geomorphological } \\
\text { differentiation }\end{array}$ & $\begin{array}{l}\text { Forming time (age) of geomorphological levels. } \\
\text { Relief types. Genesis of sedimentations. } \\
\text { Homogeneous texture in space images (regional } \\
\text { generalization level) }\end{array}$ \\
\hline $\begin{array}{l}\text { 6. Cycle of } \\
\text { geosystem } \\
\text { development and } \\
\text { series of } \\
\text { geosystem } \\
\text { development }\end{array}$ & Moistening differentiation & $\begin{array}{l}\text { Moistening type. Character of drainage. } \\
\text { Transformation of zonal bioclimatic indicators as } \\
\text { a result of substances and energy fluxes. } \\
\text { Homogeneous texture in space and aerial images } \\
\text { (local generalization level) }\end{array}$ \\
\hline $\begin{array}{l}\text { 7. Type of terrain } \\
\text { (mesogeochore) }\end{array}$ & $\begin{array}{l}\text { Group morphogenetic } \\
\text { feature of landscape units } \\
\text { (urochishche or } \\
\text { microgeochore) }\end{array}$ & $\begin{array}{l}\text { Genetic and morphological similarity of dominant } \\
\text { and typical landscape units (urochishches). } \\
\text { Combination type of lithologic-facial complexes, } \\
\text { drainage level. Homogeneous texture in space and } \\
\text { aerial images (local generalization level) }\end{array}$ \\
\hline $\begin{array}{l}\text { 8. Type of } \\
\text { landscape unit } \\
\text { (urochishche or } \\
\text { microgeochore) }\end{array}$ & $\begin{array}{l}\text { Structural-dynamic unity } \\
\text { of facies (geotopes) }\end{array}$ & $\begin{array}{l}\text { Combination of facies types in one factor- } \\
\text { dynamic range. Mesorelief types. Lithologic-facial } \\
\text { complexes. Leading landscape-dynamic process. } \\
\text { Vegetation and soil unity. Homogeneous texture } \\
\text { in space and aerial images (local generalization level) }\end{array}$ \\
\hline
\end{tabular}


The methodology for landscape mapping includes the following sequence of operations:

- Preparation of a digital base map;

- Selection and preliminary visual interpretation of remote sensing data;

- Identification of borders of landscape units;

- Definition of connection between landscape units and landscape patterns and processes (location, absolute and relative heights, character of relief, peat accumulation, surface drainage, denudation, permafrost processes, etc.);

- Creating of map legend (landscape components, soil, geobotanical characteristics etc.).

The initial stage is the preparation of a cartographical base map. Scales of $1: 25,000$ to 1:100,000 were used for the large-scale landscape mapping. Topographic maps are necessary for the vectorization of hydrological objects. The positions of water bodies in the research area were updated using data from remote sensing of ultrahigh spatial resolution. In the final stage of this initial phase, an inspection of the topological relations of objects was carried out; errors of vectorization and incorrect positioning of objects were evaluated and corrected. The correction was carried out by visual comparison of the digitized hydrosystem and remote sensing data.

Selection of remote sensing data (Quickbird) was carried out during a preparatory stage of the research. Contemporary satellite images are the most valuable and reliable sources of information for the correction of a topographical base map and preparation of a landscape map. Different types of images taken from space, of high and ultrahigh resolution, are used for large-scale landscape mapping. In this research we used satellite images QuickBird with spatial resolution $2.44 \mathrm{~m}$. Differentiation of landscapes at the terrain-type level and type of landscape unit is based on the visual interpretation of these images and on results of field landscape research (land and aero-visual research). Interrelations between landscape structure and natural processes in the research area, evidence for which is provided by the images from space, come to light in the process of field landscape-indicator interpretation. Thus in this research we used the principle of photostructural unity (Table 1), which means that the landscape units in images have a homogeneous texture (Kozin, 2007), and methods of landscape-indicator research.

Large-scale landscape inventory maps provide an information basis for evaluation and advisory maps. The approach follows Kozin's methodology for landscape and ecological analysis and landscape assessment (Kozin, 2007). The methodology includes assessment of functions, values and stability of landscapes, and was developed in the late 1980s for oil and gas extraction areas of Western Siberia. The method has many similarities with contemporary methods of mapping and assessment of ecosystem (landscape) functions and services. Resource and ecological functions of landscapes are identified within landscapes, and an assessment of the economic (for traditional or ethnic land use) and environmental values of landscapes is carried out according to these functions. The landscapes of the research area have particular resource functions, which determine their economic value. Resource functions include both physical resources and existing types of land use. Thus among the group of resource functions we find ren-pascual (Rangifer tarandus), hunting-trade, baccamushroom, and tree-resource (for northern taiga landscape). The environmental (ecological) 
functions include, among others, habitat (biotope), climate-protecting, water-protecting, water-storage, runoff-regulatory, landscape-stabilizing, permafrost-stabilizing and erosionpreventive landscape functions. The functions, economic value and stability assessment are widely used in landscape research in Western Siberia (Kozin et al., 2007; Marshinin, 2007; Kozin et al., 2009; Idrisov et al., 2015).

Examples of inventory and evaluation maps at a scale 1:50,000 for the Samburgskoye oil and gas field territory are shown in Figure 2. Detailed information about landscape units is part of the complex legends. Part of the landscape information system can be seen in Table 2.

Nineteen types of terrain (types of mesogeochore) and 138 types of landscape unit (types of urochishche or of microgeochore) were included in the 9 series and 5 cycles of geosystem development within the mapping area (Kozin et al., 2007). For the Samburgskoye oil and gas field, the geomorphologic exponents had to be taken into account. The fifth sea plain (60-80 $\mathrm{m}$ above sea level) combines hilly forest-tundra (terrain-type I, not visible in the portions of the maps in Figure 2 (a)), low-angle undulating forest-tundra (II), and flat forest-tundra (III). The fourth lake-alluvial plain $(45-80 \mathrm{~m})$ is covered by low-angle undulating tundra (IV) and flat tundra (V). Frost mounds (VI) and linear ridges of forest-tundra (VII) are situated on the surface of the fourth and the third lake-alluvial plains. The hummocky peat (VIII), flat lacustrine peat (IX), flat tussocky swamps (X), and ridges and wet depressions (XI) occupy the third lake-alluvial plain $(30-45 \mathrm{~m})$. The first and the second terraces above the floodplains (10-20 m) include lacustrine terraces (XII), khasyreys (or former lakes; XIII), and valleys and slopes (XIV). At the geomorphological level of floodplains, we find floodplains of large rivers $(\mathrm{XV})$, floodplains of medium rivers $(\mathrm{XVI})$, small valleys $(\mathrm{XVII})$, relict valleys (XVIII), and turfy valleys (XIX). Table 2 presents landscape unit types and their basic characteristics.

An interfaced analysis of the results is carried out in the final stage; it allows establishing environmental restrictions spatially in the research area taking into account functions, values (resource value and nature protection value), and the stability of the landscapes. Landscape and ecological analyses are widely required at the project stage of oil and gas field development in Western Siberia, for environmental protection. Thus, landscape mapping allows urgent problems of land use to be solved, as well as providing information support for the subsequent landscape and ecological analyses, and for the preparation of evaluation and advisory maps. 


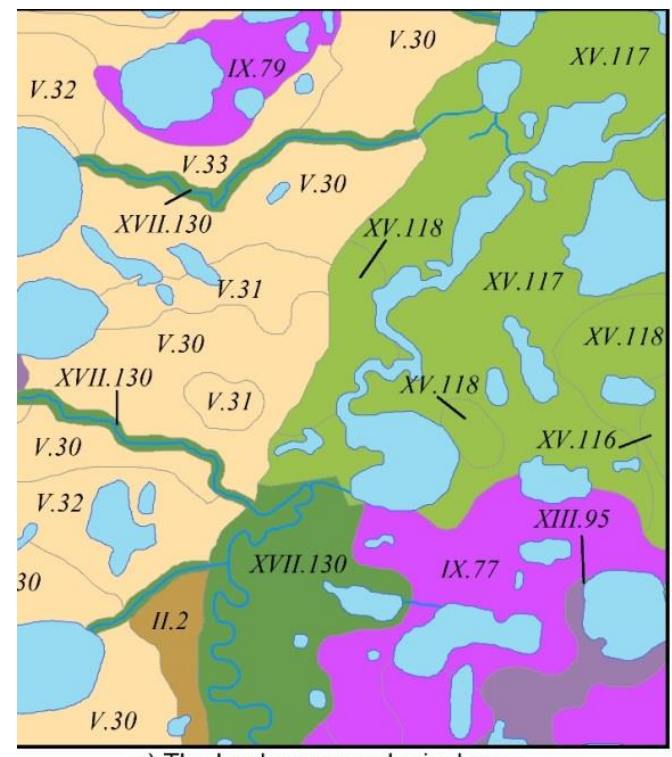

\section{Legend}

Types of terrain and types of landscape units

Low-angle wavy forest-tundra

Flat tundra

Flat lacustrine peat

Small valleys

II.2 - types of landscape units indices - XVII.130

a) The landscape-ecological map

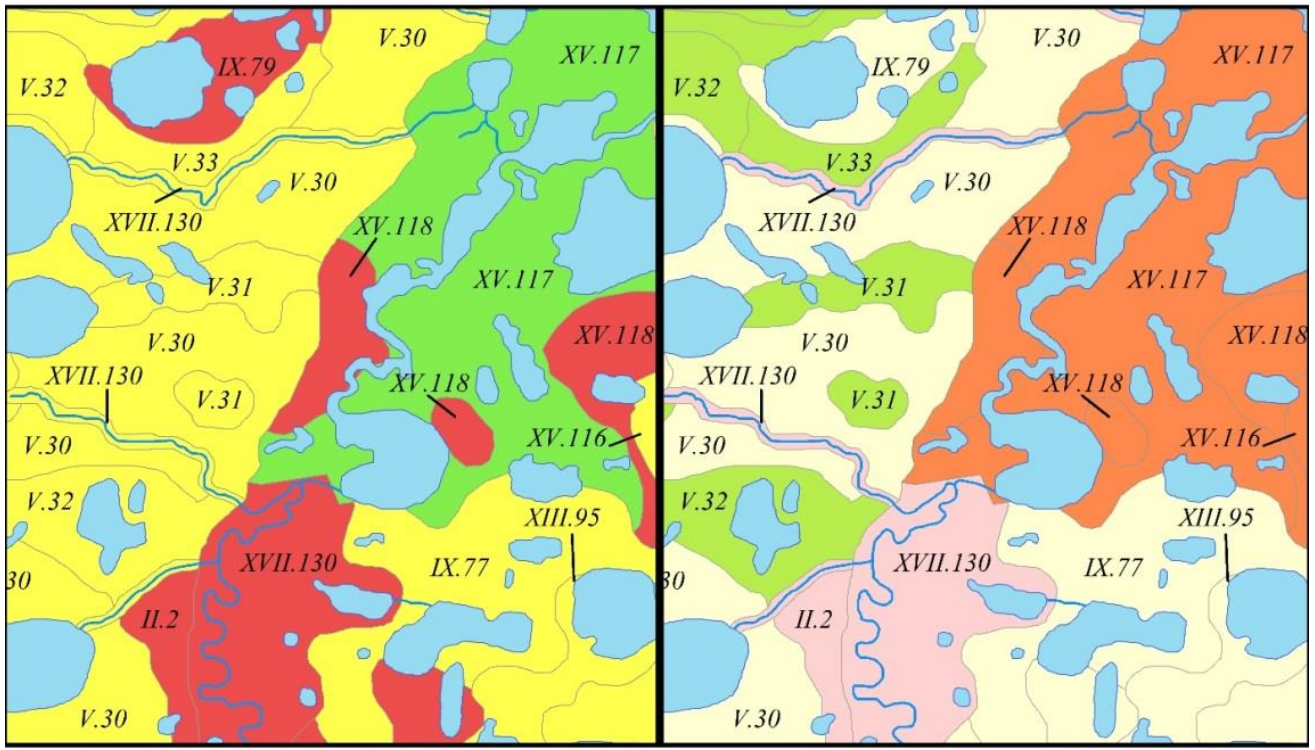

b) The resource value map

Low value

Middle value

High value c) The nature protection value map

Low value $\square$ High value

Middle value

Very high value

Figure 2: A series of landscape inventory and evaluation maps for the Samburgskoye oil and gas field territory 
Table 2: Extract from a landscape map legend (Samburgskoye oil and gas field)

\begin{tabular}{|l|l|l|}
\hline Index & Landscape type & Landscape subtype \\
\hline I.1 & Forest-tundra & Southern forest-tundra \\
\hline $\begin{array}{l}\text { Cycle of geosystem } \\
\text { development }\end{array}$ & $\begin{array}{l}\text { Series of geosystem } \\
\text { development }\end{array}$ & Geomorphological level \\
\hline $\begin{array}{l}\text { Zonal cryospheric and zonal } \\
\text { (mespheric interaction }\end{array}$ & Forest-tundra, drained & Fifth sea plain \\
\hline $\begin{array}{l}\text { Type of terrain } \\
\text { (mesochores) }\end{array}$ & $\begin{array}{l}\text { Type of landscape unit } \\
\text { (urochishche or } \\
\text { microgeochore) }\end{array}$ & Soil \\
\hline Hilly forest-tundra & $\begin{array}{l}\text { Hilly drained surface of the } \\
\text { fifth sea plain covered by } \\
\text { dwarf shrub-lichen-moss } \\
\text { tundra and larch light forest } \\
\text { on sandy loam tundra }\end{array}$ & Sandy loam tundra (podbur) \\
\hline Vegetation type & Formation class & Vegetation formation \\
\hline Forest-tundra & $\begin{array}{l}\text { Forest-tundra vegetation of } \\
\text { drained watershed }\end{array}$ & $\begin{array}{l}\text { Dwarf shrub-lichen-moss } \\
\text { tundra }\end{array}$ \\
\hline Vegetation association & Nature protection function & Resource function \\
\hline $\begin{array}{l}\text { Dwarf shrub-lichen-moss } \\
\text { tundra and larch light forest }\end{array}$ & $\begin{array}{l}\text { Climate protecting, landscape- } \\
\text { stabilizing, erosion-preventive }\end{array}$ & Bacca-mushroom \\
\hline High & Resource value & Stability \\
\hline
\end{tabular}

\section{Advantages of contemporary landscape mapping methods}

Landscape mapping is a particularly important scientific and practical task because of demands for land-use and project planning, growth in the 'objectivity' of landscape studies, and calls for modern approaches in research and the mapping of the environment. The application of modern research methods and mapping was realized in the preparation of a landscape map of Bely Island (in the Kara Sea). The initial stage for the creation of a planimetric map for part of the island's landscape on the basis of visual interpretation of remote sensing data, field research, and final interpretation and identification of terrain and landscape-unit types was carried out during summer 2015 (Druzhinin et al., 2015). The second stage of the research consisted in the assessment of the practical geomorphometrical application and the interpretation methods for the preparation of the large-scale landscape map. Results from the field research and the landscape map of a portion of northwest Bely Island were considered sources of aprioristic information. 
Images were taken from space using QuickBird and Landsat 8, and topographic maps of scale 1:50,000 were used for carrying out pre-field visual interpretation. A combination of channels 4, 3 and 2 of the Landsat system, with a resolution of $15 \mathrm{~m}$ (the processed version), and the system of coordinates of WGS-1984 UTM (Zone 42N) was used for carrying out visual interpretation. QuickBird satellite images were received with a spatial resolution of $2.44 \mathrm{~m}$. The mapping procedure was carried out by a group of researchers and students at the Institute of Earth Sciences (Tyumen State University). The preparation of a planimetric map for part of the landscape was performed in the program ArcGIS 10.3 complex. Figure 3 illustrates some of the results for the visual interpretation of Bely Island.

Field research on Bely Island's landscape structure was conducted using route researches and detailed research of landscape components in sample areas in the northwest of the island. Twelve landscape profiles (between 10 and 20 metres apart) and measuring up to $1 \mathrm{~km}$ in length were characterized; detailed complex descriptions in 70 sample areas and representative points were carried out during the field research, and a database of routes and points of research was created using ArcGIS. Final map processing included correction of a planimetric part of the landscape map; information about terrain types and types of landscape unit in the study area was added to the database. Types of terrain are colour-coded in the final map; indices are designated types of landscape unit. The configuration of the map is complemented by photographs and data for some of the main mapped units.

Contemporary methods of data processing and the use of remote sensing data as a basis for spatial analysis have broad applications in geographic research (Kozlov, 2006; Sharyy, 2006). The use of results from digital elevation model analysis and the supervised processing of space information satellite imagery are of interest for landscape mapping (Chaban, 2013; Svidzinskaya, 2013). The morphometric analysis of the mapped area was carried out with the use of ALOS World 3D and AsterDEM (open source) in the SAGA program package. 


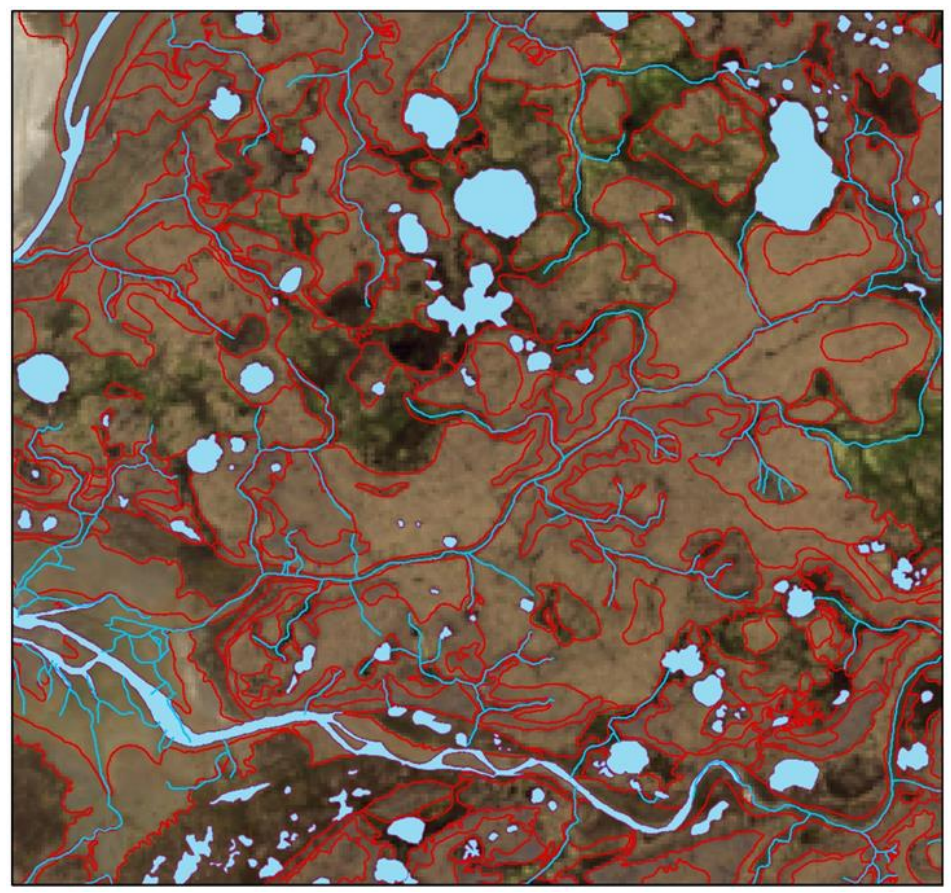

Figure 3: The results of visual interpretation (Bely Island, Kara Sea)

Data filtration by means of GIS SAGA was carried out in order to eliminate mistakes made during the initial stage. The analysis of a relief model included definition of biases, horizontal and planned curvature, and detection of features of superficial drainage. Characteristics of the relief as the basis for landscape differentiation at the level of terrain types are important for landscape map preparation. Curves in the relief (thalwegs, edges of slopes and terraces, etc.) are important natural boundaries and borders of terrain types. Considerable experience in the application of a geomorphometric method application has been accumulated during large-scale mapping (Kozlov, 2006; Sharyy, 2006).

The geomorphometric analysis of ALOS World 3D and Aster DEM data has allowed increasing objectivity in the analysis of landscape structure. The basic landscape structure is supplemented with data for horizontal landscape connections, distribution of solar radiation, and more exact delimitation of terrain types. Despite its considerable advantages, the use of digital elevation models for landscape mapping of Arctic landscapes has some limitations. A large number of artifacts Aster DEM does not allow to analyze the landscape structure at the level of the type of landscape units.

The classification of the remote sensing data was carried out using the ENVI program package and the QGIS module semi-automatic classification plug-in (Karpachev, 2016). Types of terrain border are defined by carrying out cluster analysis (ISODATA) of Landsat 8 satellite images in using ENVI. The cluster analysis gives comparable results to those of visual interpretation. The classification of high-resolution satellite images gives better results for features of landscape structure at the level of landscape-unit types (Figure 4). 


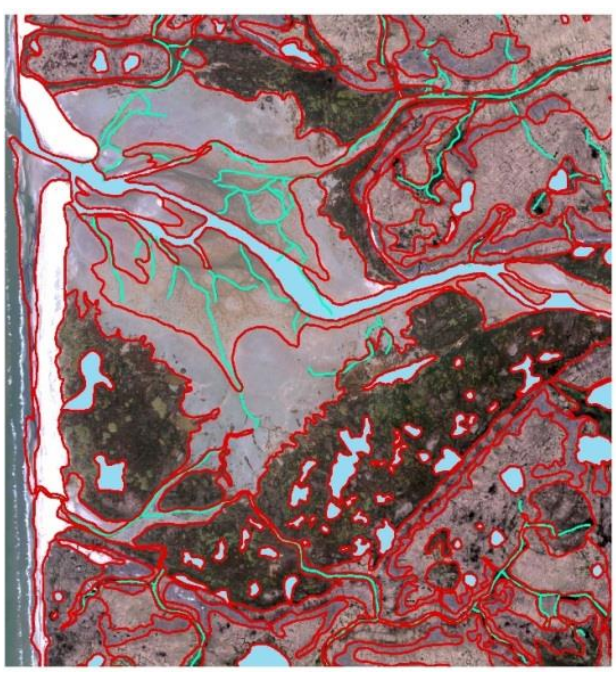

(a)

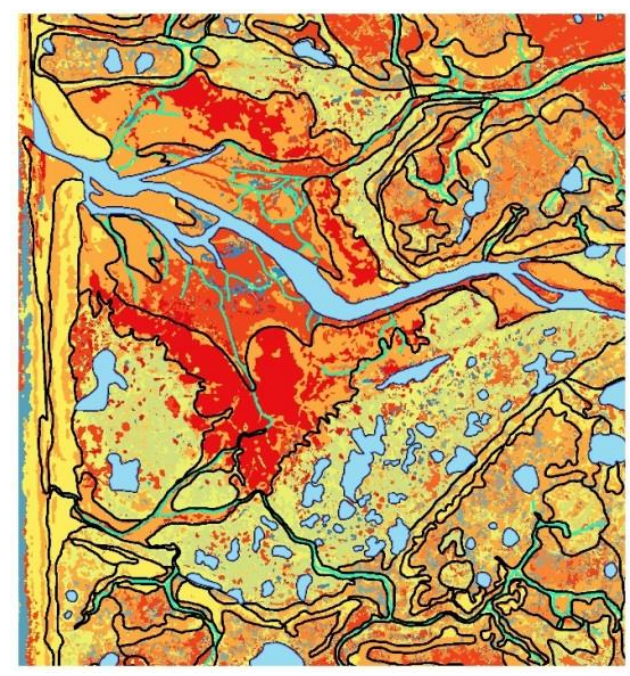

(b)

Figure 4: The results of (a) visual and (b) supervised interpretation (Bely Island, Kara Sea)

\section{Conclusion}

Large-scale landscape mapping has great practical value, allowing a wide range of practical and economic problems to be solved. These advantages are especially important for the Arctic territories, which remain little studied in many respects and for which large-scale cartographic materials are not available. The development of modern methods for large-scale landscape mapping is necessary for the geoinformational support of development projects in the Arctic. Applying the methods of geomorphometry and the classification of satellite images allow increased objectivity of the landscape analysis of the territories being explored and a reduction in the time spent on map preparation.

\section{References}

Beruchashvili N.L. \& Zhuchkova V.K. (1997), The complex physical-geographic research methods. Moscow, Moscow State University Publishing House, 320 p. (In Russian).

Chaban L.N. (2013), The automatic aerospace information processing in the mapping of geospatial data. Manual. Moscow, Mocsow Institute of engineers of geodesy, aerophotosurvey and mapping. 96 p. (In Russian)

Druzhinin A.N., Idrisov I.R. \& Marshinin A.V. (2015), The Arctic tundra landscapes mapping experience on the example of the northwestern part of Belyy Island (the Kara Sea). The geoinformational mapping of regions of Russia. The Materials of 7th All-Russian scientific and practical conference (Voronezh, 10-12 December 2015). Voronezh State University. Voronezh, "Nauchnaya kniga" Publishing House. Pp. 46-54. (In Russian)

Idrisov I.R, Kozin V.V., Marinskikh D.M. \& Marshinin A.V. (2015), Landscape analysis for environmental planning, management and decision-making by oil-and-gas field development: 
experience from Western Siberia, Russia. International Geographical Union Regional Conference. Geography, Culture and Society for our Future Earth. 17-21 August 2015, Moscow, Russia. IGU 2015 Book of Abstracts. IGU 2015 - 4592. P. 620.

Idrisov I.R., Kozin V.V., Marshinin A.V. \& Marinskikh D.M. (2006), The geoinformational provision of the environmental audit of the oil and gas enterprises (on the example of the Vyngapurovskoye oil field). The problems of the regional ecology. N3. Pp. 88-95. (In Russian).

Karpachev A.P. (2016), The experience of the Landsat space image classification by Semi-Automatic Classification Plugin in QGIS. 25.06.2016. http://gis-lab.info/qa/landsat_qgis_scp.html. (In Russian)

Kotlyakov V.M. \& Komarova A.I. (2007), Geography: Concepts and Terms: Dictionary in five languages: Russian - English - French - Spanish - German. Rus. Acad. of Science. Moscow, Nauka. 859 p.

Kozin V.V. (2007) The landscape analysis in the oil and gas producing region. Tyumen, Tyumen State University Publishing House. 240 p. (In Russian)

Kozin V.V \& Marinskikh D.M. (1996) The basic landscapes classification of the north of the West Siberian lowland. Problems of geography and ecology of Western Siberia. Tyumen, Tyumen State University Publishing House. P. 47-59. (In Russian)

Kozin V., Marinskikh D. \& Marshinin A. (2009), The landscape ecological analysis for decisionmaking by of oil-and-gas field development in the context of environmental sustainability: experience from West Siberia, Russia. In: J. Breuste, M. Kozova and M. Finka (Eds.). European Landscapes in Transformation: Challenges for Landscape Ecology and Management. European IALE Conference 2009. Salzburg (Austria), Bratislava (Slovakia). P. 304-305.

Kozin V.V., Marinskikh D.M., Marshinin A.V. \& Idrisov I.R. (2007), The landscape ecological analysis for environmental impact assessment of oil-and-gas production and transport: experience from north-west of Siberia, Russia. 25 Years of Landscape Ecology: Scientific Principles in Practice. Proceeding of the 7th IALE World Congress - Part 2. P. 879.

Kozlov D.N. (2006), The landscape cover taking stock by spatial analysis methods for purposes of the landscape planning. The materials of the International School-Conference "Landscape planning. Common bases. Methodology. Technology". Moscow, Moscow State University, the faculty of geography. Pp. 117-137. (In Russian)

Marinskikh D.M. (2003) Landscape-ecological analysis of the territory of the Urengoy oil and gas condensate field. PhD Thesis. 217 p. (In Russian).

Marshinin A.V. (2007), Landscape-ecological structure and spatial organization of insular geosystems of Western Siberia. Landscape Analysis for Sustainable Development. Theory and Applications of Landscape Science in Russia. Alex Publisher, Moscow. P. 114-120.

Milkov F.N. (1966), The landscape geography and questions of practice. Mocsow, Mysl Publishing House. 256 p. (In Russian)

Milkov F.N. (1970), The landscape sphere of the Earth. Mocsow, Mysl Publishing House. 207 p. (In Russian)

Sharyy P.A. (2006), The geomorphometry in sciences of the Earth and ecology; the review of methods and applications. The Bulletin of Samara scientific centre of Russian Academy of Sciences. N8 (2). Pp. 458-473. (In Russian)

Svidzinskaya D.V. (2013): The basic geomorphometric parametres: theory. 31.11.2013. Retrieved from http://gis-lab.info/qa/geomorphometric-parameters-theory.html. (In Russian) 